\title{
"Securing our Survival (SOS)": Non-State Actors and the Campaign for a Nuclear Weapons Convention through the Prism of Securitisation Theory*
}

\author{
Renata H. Dalaqua \\ Brazilian Centre for International Relations (CEBRI), Brazil
}

This article analyses the security practices of the anti-nuclear movement in the post-Cold War period through the prism of securitisation theory. By exploring Buzan and Wæver's conceptual developments on macrosecuritisations, the practices involved in the struggle against the Bomb are interpreted as securitising moves, in which the anti-nuclear movement is the leading securitiser. In the capacity of securitising actors, nuclear abolition activists argue that nuclear disarmament, under a Nuclear Weapons Convention (NWC), would be the only way to protect humankind from the threat posed by the existence of nuclear weapons. The empirical analysis of these non-state actors and their campaign for a NWC shows that, despite uttering security, the anti-nuclear movement has so far failed to achieve the proposed security measure, that is, nuclear disarmament. Nonetheless, securitisation has been instrumental for these non-state actors as a way of raising an issue on the agenda of decision-makers and urging them to take action.

Keywords: International Relations; non-state actors; nuclear disarmament; securitisation theory.

\section{Introduction}

The history of the peace movement has been the subject of several outstandI ing books and the impact the "arms control transnational network" had upon

1 The author would like to thank Dr. Matthieu Chillaud, the supervisor of the MA dissertation that resulted in this article, and the two anonymous reviewers for their valuable comments and suggestions. Responsibility for any error or omission lies solely with the author. 
international politics during the Cold War has been vastly researched and now constitutes a well-established literature in the field of international relations. ${ }^{2}$ Nevertheless, a deep understanding of the advocacy of nuclear disarmament as an attempt to securitise nuclear weapons is yet to be presented.

In order to overcome this gap and shed light on the role of discourse as an important non-material source of power in international military affairs, the present article examines the campaign led by non-governmental organisations (NGOs) ${ }^{3}$ for a Nuclear Weapons Convention (NWC) through the prism of securitisation theory. Exploring Barry Buzan and Ole Wæver's conceptual developments on macrosecuritisations (2009), it was possible to interpret the practices involved in the struggle against the Bomb as securitising moves in which the anti-nuclear movement is the leading securitiser - that is, the actor that mobilises different resources with the purpose of constructing a specific issue as a threat.

With the purpose of identifying patterns of representation and establishing networks of meanings that are invariably present in the construction of threats, a discourse analysis of the most central texts produced by anti-nuclear NGOs advocating for the establishment of a NWC was conducted. It became clear that, despite uttering security, the anti-nuclear movement has thus far failed to achieve the proposed security measure. Nonetheless, this attempt at securitisation has been instrumental for these non-state actors, as the alarmist tone of the discourse has provided them with a loud voice in international military affairs.

Before presenting the empirical analysis and its main findings, an overview of the macrosecuritisation concept will be provided. This theoretical exercise seems particularly worthwhile as there are few studies that make use of this higher-level securitisation framework.

By adopting a fresh perspective on the study of the anti-nuclear movement, this article intends to provide a better understanding of the power of non-state actors in international politics, and also to highlight the instrumentality of securitisation as a way of raising an issue on the agenda of decision-makers and urging them to take action (Vuori, 2008, p. 76).

2 For a great account of the history of the nuclear abolition movement, see the three volumes of Lawrence Wittner's collection The struggle against the Bomb (Wittner, 1993, 1997, 2003). On the arms control transnational network of the Cold War, see Adler (1992) and Risse-Kappen (1994).

3 In this article, NGOs are defined in conformity with the United Nations legal framework that governs NGO participation, Resolution 1996/31 of the Economic and Social Council (ECOSOC). According to this resolution, "any such organization that is not established by a governmental entity or intergovernmental agreement shall be considered a non-governmental organization". In this resolution, "organization" may refer to NGOs at the national, subregional, regional and international levels (UN Economic and Social Council, 1996). 


\section{Understanding Macrosecuritisations}

Throughout the years, Buzan and Wæver have employed the securitisation framework, mainly in studies dealing with regional security dynamics. Recently, however, the authors came to the conclusion that the study of securitisation processes involving referent objects placed at the system level had been somewhat neglected. The efforts regarding the American-led "Global War on Terrorism" (GWoT) and the growing visibility of the transnational environmental movement motivated these authors to conduct a modest revision of their original framework, adjusting it to the study of higher-level securitisations.

In "Macrosecuritisation and security constellations: reconsidering scale in securitisation theory" (hereafter, "Macrosecuritisation"), Buzan and Wæver adopted a slightly critical approach to refer to their previous focus on the regional level. The authors stated that elements of realist thinking were evident in the predominance of states and national security concerns in what could be considered "an egotistical model of security" (Buzan and Waever, 2009, p. 256). Although this model came close to reality, it was not appropriate to analyse particular occasions when over-arching international security problems dominated the global structure of security. To remedy this weakness, they proposed the concept of macrosecuritisation, which denotes securitisations on behalf of referent objects located at levels higher than the middle one and "which aim to incorporate and coordinate multiple lower level securitisations" (Buzan and Waever, 2009, p. 257) .

As could have been anticipated, these higher order securitisations share many of the features that characterise lower level ones. Macrosecuritisations also require securitising actors, which mobilise different resources, with the purpose of constructing a specific issue as a threat, on behalf of a referent object and before the relevant audience(s). Nonetheless, due to their particular macro quality, macrosecuritisations usually establish hierarchical relations with other securitisations, possibly incorporating or coordinating them. Another distinguishing feature of macrosecuritisations is that, when powerful, they can "operate as the interpretive framework for other securitisations" (2009, p. 265).

This was the case during the Cold War, when security concerns at lower levels were re-articulated and framed in terms of the East-West conflict. In order to properly identify a macrosecuritisation, one can compare it to other lower level securitisations, according to three different criteria. The obvious one concerns the level of the referent object: individual, group, unit, civilizational, system or global. A second aspect for comparison refers to comprehensiveness; that is, the extent to which the macrosecuritisation effectively reaches and structures securitisations in different sectors. According to this criterion, different degrees of comprehensiveness will determine whether the securitisation is a niche, a partial or inclusive one. A third point for consideration would be the degree of success 
achieved by the macrosecuritisation, which can be evaluated according to the level of support demonstrated by the relevant audience. Buzan and Wæver (2009) carefully point out that the degree of success does not strictly determine "whether something is a macrosecuritisation or not, but whether it is a powerful one" (p. 259).

It is interesting to note that the authors avoid establishing firm standards that determine whether or not a macrosecuritisation has been put in place. Instead, they propose that the analyst observe the power of a securitisation indirectly, assessing the impact it has on security constellations. This lack of concrete criteria to evaluate whether or not a securitisation has occurred is one of the main criticisms facing the Copenhagen School. ${ }^{4}$

The idea of constellations had already figured in other texts by authors associated with the Copenhagen School, usually in the context of Regional Security Complex Theory (RSCT). Nonetheless, in "Macrosecuritisation" the concept is re-examined from a macro perspective. In this sense, the authors refer to constellations as sets of interlinked securitisations and their respective cross-levels, cross-sectors relations. Thus, it becomes clear that constellations are generated by macrosecuritisations, which structure and organise interdependent securitisations (Buzan and Waever, 2009, p. 259). Therefore, the study of security constellations allows the security analyst to see the "bigger picture"; that is, the large-scale patterns of interlinked securitisations. On some occasions, these patterns are marked by the existence of a powerful macrosecuritisation, which incorporates and/ or frames many of the lower level securitisations. Through such processes, macrosecuritisations can generate system-spanning constellations - as was the case of the Cold War (Buzan and Waever, 2009, p. 268).

4 In the monograph Security: a new framework for analysis (Buzan et al., 1998), there are passages in which the authors state that the securitising claims must be accepted by the relevant audience and exceptional measures must be adopted so that a securitisation can be achieved (Buzan et. al., 1998, p. 26). Nevertheless, on other occasions, Buzan et al. (1998) lower their standards, affirming that the permission to "break free of the normal procedures and rules" already signifies that a securitisation has been accomplished (p. 25). In one of these confusing statements, the authors affirm that "the exact definition and criteria of securitization is constituted by the intersubjective establishment of an existential threat with a saliency sufficient to have substantial political effects" (p. 25). However, they do not explore the dynamics of this intersubjective process, nor do they elaborate on what their understanding of "normal political procedures", "relevant audience" and "substantial political effects" is. This might be a conscious decision, since all these categories can be considered case dependent, and establishing rigid parameters would perhaps make the securitisation framework impractical. Yet, the absence of a frame for how securitisations are successful or not has led to disparate understandings of what the construction of a threat image exactly entails. For critical assessments of the Copenhagen School, see Balzacq (2011a) and Stritzel (2007).

5 The term "Copenhagen School" became a commonly used shorthand to refer to the collective work of Buzan, Wæver and other scholars associated with the Copenhagen Peace Research Institute (COPRI). 
Yet, establishing powerful macrosecuritisations can be quite expensive and involve strenuous efforts. Political capital and other sorts of resources are employed by the securitising actors in different practices that can contribute to the construction of a threat. In the case of macrosecuritisations, Buzan and Wæver argue that the creation of universalist ideologies, embracing strong political claims, facilitates the establishment and maintenance of the threat image. Since these universalist beliefs provide a basis for the creation and reinforcement of core identities, they also make the construction of shared understandings and shared threat perceptions possible. Not surprisingly, universalisms play a big part in the process of winning over the relevant audiences - domestic and international ones. Based on the main argument in which the ideology is rooted, Buzan and Wæver (2009) identified four types of universalisms: inclusive, exclusive, existing order universalism and physical threat universalism (pp. 260-61).

They argued that each kind of universalism influences the dynamics of the macrosecuritisation and their respective constellations in different ways. The anti-nuclear macrosecuritisation of the Cold War, for instance, was based on a variant of physical threat universalisms, since the securitising actors argued that nuclear weapons posed a threat to the physical fate of humanity (Buzan and Waever, 2009, p. 261). In this case, particular features of the alleged threat, such as its unparalleled power of destruction and its indiscriminate nature, underpinned a securitisation that could eventually be full-scale.

\section{Macrosecuritisation of Nuclear Weapons in the Cold War Period}

In the context of the Cold War, Buzan and Wæver approached the anti-nuclear securitisation from the perspective of the activists who have been advocating for nuclear disarmament ever since the first bomb was dropped in 1945. From this point of view, Buzan and Wæver (2009) stated that "oppositional civil society groups" were the main carriers of this macrosecuritisation (p. 270) and therefore provided an innovative account of the anti-nuclear movement during the Cold War. According to them, anti-nuclear securitisers construed the threat of nuclear weapons in connection with other security concerns, like the devastation of the environment caused by nuclear tests and the danger of war between the rival superpowers. Connecting various concerns pertinent to discrete sectors, the anti-nuclear movement was capable of establishing an inclusive macrosecuritisation (Buzan and Waever, 2009, p. 259).

From the viewpoint of nuclear non-proliferation, this was a relatively successful macrosecuritisation; nuclear proliferation was established as a threat and arms control mechanisms and the NPT regime were put in place to avoid this problem. Evidently, the anti-nuclear movement was not the only actor interested in preventing proliferation. At the 
same time that non-proliferation represented the "genuine fear that the spread of nuclear weapons would increase the chance of them being used", it also had a strong appeal for the two superpowers, who sought to maintain their privileged status and military pre-eminence (Buzan and Waever, 2009, p. 270). From the perspective of disarmament, however, the anti-nuclear movement was not able to convince the relevant audience that outlawing and eliminating nuclear weapons constituted an appropriate solution to the nuclear threat.

Taking these mixed results into account, Buzan and Wæver (2009) provided the general picture of this securitisation, affirming that "Compared to the dominant securitisation pattern of the Cold War, securitisatin of nuclear weapons, though aiming at universality, was much less widely held [...] But it nevertheless represented a durable and in some ways influential minority macrosecuritisation with an active global following" (p. 270).

Although succinct, this assessment of the anti-nuclear macrosecuritisation of the Cold War is of enormous importance for several reasons. Remarkably, it signified a change of posture towards the securitisation of nuclear weapons. Before this article, Buzan and Wæver had only mentioned the securitisation of nuclear weapons in situations where states were the securitising actor and proliferation in specific countries was in fact the issue being constructed as a threat (Buzan et al., 1998, p. 55; Buzan and Waever, 2003, p. 13). The focus on the global level allowed the authors to see the securitising efforts made by the anti-nuclear movement that, until then, had been overlooked by the literature on securitisation. In "Macrosecuritisation", Buzan and Wæver not only confirmed that securitisation is a process that can take place at every level but they also strengthened the claim that non-state actors can effectively play the role of securitisers. As a result, they inaugurated a new perspective on the study of the anti-nuclear movement, asserting the feasibility of examining the nuclear abolition discourse as an attempt to securitise the existence of nuclear weapons.

\section{Security Dynamics after the Cold War and the Campaign for a Nuclear Weapons Convention (NWC)}

The collapse of the Soviet Union brought an end to the East-West conflict and the ideological rivalry that had underpinned the bipolar power structure. According to Buzan and Wæver (2009), the end of the Cold War was "a massive act of macrodesecuritisation", which led to the extinction of the security constellation that had been generated by the two rival macrosecuritisations (p. 270). As for the perceived threat posed by nuclear weapons, it was largely diluted amid the wave of general optimism that became apparent in international relations during the early 1990s. 
Even though cooperative patterns of relations started to emerge between the US and Russia and there was an intensification of international negotiations concerning arms control agreements and reductions, these did not necessarily mean that steps towards complete elimination of nuclear weapons were being taken. As the Nuclear Weapon States $(\mathrm{NWS})^{6}$ continued to include nuclear deterrence in their defence doctrines, the wave of optimism that followed the end of the Cold War soon turned into disappointment. It became clear to nuclear abolition activists that none of the NWS considered nuclear disarmament a viable option. Moreover, the persistence of vertical and horizontal proliferation, ${ }^{7}$ as well as the inability to put an end to nuclear testing, reminded the anti-nuclear movement of how distant the world was from nuclear abolition.

Despite the lessening of international tensions and the decrease in popular mobilisation, peace activists and nuclear abolition organisations kept on lobbying for nuclear disarmament. By different means, nuclear abolition activists and NGOs continued to draw attention to the dangers posed by the very existence of nuclear weapons. Considering the nuclear threat an urgent question, a matter of life and death to all humanity, these abolitionists conducted campaigns and staged demonstrations that were charged with securitising claims. In order to tackle this problem, the anti-nuclear movement suggested that different steps be taken, all leading to the total elimination of nuclear weapons. According to them, the time to act was always "now"; otherwise, proliferation would continue to take place. In the nuclear abolition discourse, an increased number of nuclear weapons represented a bigger chance they would be used - destroying "whole cities, populations, countries or even civilisation" (HILL, 2007).

Among the main campaigns of the anti-nuclear movement in the post-Cold War period are the fight against nuclear tests, the World Court Project - which requested an advisory opinion from the International Court of Justice (ICJ) on the legality of the threat or use of nuclear weapons - and the Campaign for a Nuclear Weapons Convention (NWC). The latter emerged in the 1990s, after the ICJ issued its verdict, comprising six different findings. Remarkably, one such conclusion was the declaration that "there exists an obligation to pursue in good faith and bring to a conclusion negotiations leading to nuclear disarmament in all its aspects" (International Court of Justice, 1996).

$6 \quad$ Nuclear Weapon States are here defined in accordance with the Nuclear Non-Proliferation Treaty (NPT); that is, the countries which have manufactured and exploded a nuclear weapon or other nuclear explosive device prior to 1 January, 1967 - China, France, Russia, the United Kingdom and the United States. See the Treaty on the Non-Proliferation of Nuclear Weapons (1968).

7 Horizontal proliferation is used to refer to the acquisition of nuclear weapons by hitherto nonnuclear weapon states. Accordingly, vertical proliferation refers to the further development, production, and deployment of nuclear weapons by nuclear weapon states. 
In 1996, as a follow-up to the ICJ's ruling, the UNGA first adopted a resolution calling on all states "to commence multilateral negotiations leading to the conclusion of a nuclear-weapons convention prohibiting the development, production, testing, deployment, stockpiling, transfer, threat or use of nuclear weapons and providing for their elimination" (UN General Assembly, 1996).

Despite this apparent consensus on the idea of a Nuclear Weapons Convention (NWC), it had been met with scepticism by those who asserted the unlikelihood of obtaining agreements on the legal and technical requirements of such a treaty. In the absence of concrete proposals coming from states, experts from different organisations came together and drafted themselves a model NWC. It was a draft of a legally binding international convention, regulating the elimination and institutionalising the prohibition of the development, testing, production, stockpiling, transfer, use and threat of use of nuclear weapons. Equipped with this new tool, a network of nuclear abolition INGOs and NGOs started campaigning for international negotiations leading to the establishment of a NWC as the solution to the nuclear threat.

Collaborating with states willing to advance the goal of nuclear abolition, the anti-nuclear movement managed to include the model NWC in the "general and complete disarmament" agenda of the fifty-second session of the UNGA, in 1997. At the request of Costa Rica, the Model NWC was translated into the UN official languages and circulated to the UN member states. In his introductory letter, the Ambassador of Costa Rica presented the Model NWC as an initiative by civil society, aimed at creating legal instruments in order to achieve the goal of total elimination of nuclear weapons. He also stated his belief that states should carry through with this enterprise (UN General Assembly, 1997a). This was an important moment for the nuclear abolition movement. As the draft reached national delegations, there was a real chance that it would be incorporated into their discussions. However, with regard to the resolutions adopted by this session of the UNGA, no substantive progress on nuclear disarmament was achieved apart from the second resolution on the follow-up of the advisory opinion of the ICJ (UN General Assembly, 1997b).

As a document for discussion, the Model NWC that circulated in the UNGA received comments, criticisms and suggestions for improvement. It was then reviewed by a consortium of experts and published in Security and Survival: The case for a Nuclear Weapons Convention (1999); a book by the International Physicians for the Prevention of Nuclear War (IPPNW), the International Association of Lawyers against Nuclear Arms (IALANA), and the International Network of Engineers and Scientists against Proliferation (INESAP). In addition to the improved version of the Model NWC, Security and Survival contained comments and critical questions regarding different aspects of the treaty. Intended to a broader audience than the political elite, this publication also contained advocacy 
statements, poetry, cartoons and pictures related to the subject of nuclear weapons. In addition to the printed version, the book was also made available online.

The campaign for a NWC continued to be one of the major projects of the anti-nuclear movement throughout the 2000s. In 2007, as the goal of a nuclear weapon-free world became once again part of the security establishment's rhetoric, the Model NWC and the texts that were part of Security and Survival were updated and reprinted. In this context, IPPNW, IALANA and INESAP came together again and published Securing our Survival (SOS): The case for a Nuclear Weapons Convention. In accordance with the title, securitising claims permeated all the different texts contained in this book.

Again in 2007, Costa Rica submitted a working paper on the NWC to the 2007 NPT Preparatory Committee (NPT Preparatory Committee, 2007). Additionally, the Costa Rican and Malaysian governments requested that the updated model NWC be circulated in the sixty-second session of the UNGA (UN General Assembly, 2008). Regarding the resolutions adopted by this session of the General Assembly, not much progress was made, except for the annual resolution on the follow-up of the ICJ's advisory opinion (UN General Assembly, 2007).

Nevertheless, 2007 marked the beginning of a revival of interest in the cause of nuclear abolition. The Wall Street Journal op-ed "A world free of nuclear weapons" (2007), signed by former US Secretaries of State George P. Shultz and Henry A. Kissinger, together with former Secretary of Defence William J. Perry and former Senator Sam Nunn, is commonly referred to as the starting point of this trend. This op-ed had repercussions at the national and international levels, generating a wave of positive responses coming from different parts of the world (Dalaqua, 2011).

In that same year, different nuclear abolition INGOs joined efforts and launched the International Campaign to Abolish Nuclear Weapons (ICAN). An umbrella organisation, ICAN included NGOs from all around the world. Modelled on the successful International Campaign to Ban Landmines (ICBL), ICAN's main objective was to promote the "security action", the abolition of nuclear weapons through the establishment of a NWC.

As the calls for nuclear disarmament grew stronger, the WSJ published another op-ed signed by Schultz et al. in the beginning of 2008. Under the title "Toward a nuclear-free world", the four American statesmen reinstated the opinion expressed in the previous year and affirmed the need to reduce reliance on the "deadliest weapons ever invented". According to them, the world was facing a "nuclear tipping point" and it was necessary to act fast to avoid the "nuclear precipice" and end nuclear weapons as a threat to the world (Schultz et al, 2008).

Likewise, UN Secretary-General Ban Ki-moon presented his five-point plan on nuclear disarmament. Addressing a meeting organised at the United Nations by the East-West 
Institute, Ki-moon mentioned the threats posed by nuclear weapons, which he said can have "horrific consequences". With the purpose of overcoming the nuclear threat, the Secretary-General put together a plan. Already in the first point, he urged all NPT parties, in particular the NWS, to consider negotiating a NWC without delay (Ki-moon, 2008).

Strengthening the calls for a nuclear weapon-free world, the Global Zero movement was launched in December 2008. Congregating high-profile political figures and former politicians and officials of the Cold War era, ${ }^{8}$ Global Zero defended phased and verified reductions, as well as a binding agreement to eliminate all nuclear weapons by a certain date (Global Zero Commission, 2009). The political and social capital of the members of this group proved to be a catalysing factor and, shortly after it had been founded, Global Zero representatives held meetings with military officials and political leaders from key countries, such as the US and Russia (Corera, 2008).

Far more prominently than ever before in the post-Cold War period, nuclear weapons were being depicted by top-rank politicians and high-level state officials as a threat to the survival of humankind. In the US, this endorsement of the goal of a world free of nuclear weapons set the political mood for the presidential campaign that was under way in 2008 . Soon after coming to power, President Obama gave voice to his "vision of zero", during the so-called "Prague Speech". In the capital of the Czech Republic, in April 2009, President Obama enunciated his belief on the feasibility of a world free of nuclear weapons. According to him,

The existence of thousands of nuclear weapons is the most dangerous legacy of the Cold War [...] Today, the Cold War has disappeared but thousands of those weapons have not. In a strange turn of history, the threat of a global nuclear war has gone down, but the risk of a nuclear attack has gone up [...] And no matter where it happens, there is no end to what the consequences might be - for our global safety, our security, our society, our economy, to our ultimate survival [...] So today, I state clearly and with conviction America's commitment to seek the peace and security of a world without nuclear weapons (The White House, 2009).

Sensing a window of opportunity, nuclear abolition activists intensified their lobbying practices before and during the 2010 NPT Review Conference. A day prior to the Conference, 15,000 people gathered at an anti-nuclear rally in New York, on May 2, 2010. At the Conference, 28 countries specifically referred to a NWC. Additionally, the NonAligned Movement (NAM) - representing 118 countries - voiced demands for a time-bound

8 Signatories included former US President Jimmy Carter, former Soviet leader Mikhail Gorbachev, former German Foreign Minister Hans-Dietrich Genscher and former British Defence Secretary Malcolm Rifkind. For the complete list of signatories, see http://www. globalzero.org/full-list-signatories [Retrieved on 21 July 2011]. 
commitment to achieve nuclear abolition under a NWC (Wright, 2010, pp. 52; 53). This time, the Conference agreed on a final agreement, in which efforts aimed at commencing negotiations on a NWC were finally acknowledged (NPT Review Conference, 2010).

\section{Trying to Securitise Nuclear Weapons in Different Settings}

The analysis of the main developments involving the securitisation of nuclear weapons in the post-Cold War period supports the view of securitisation as a complex, historical process. As such, they involve a plurality of practices, actors and audiences. Even though state actors have incorporated securitising claims to their rhetoric, this article seeks to investigate the securitisation of nuclear weapons from the perspective of its long-standing advocates, the anti-nuclear movement. Through this approach, the present article intends to advance the study of non-state actors' engagement in international military affairs and to shed light on the possible instrumentality of securitisation as a way of raising an issue on the agenda of decision-makers and urging them to take action.

The array of different practices involved in the securitisation promoted by the anti-nuclear organisations points to the existence of various "battle fronts" where the construction of nuclear weapons as a threat is fought; that is, it is negotiated between the securitiser and the audiences. In order to gain a better understanding of the variations in the form, content and success of different securitising moves, Salter (2008) borrowed the concept of "setting" from Goffman's dramaturgical analysis (p. 322). According to Salter (2008), "the setting of a securitising act includes the stage on which it is made, the genre in which it is made, the audience to which it is pitched, and the reception of the audience" (p. 328). This dramaturgical approach comes to remedy the exaggerated emphasis on the internal elements of discourse that is part of the speech-act model proposed by the Copenhagen School. As Salter has observed, the success of a securitisation cannot be reduced to the formal syntax of the speech; it is also related to the existence of a common, social grammar, which encompasses the "particular history, dominant narrative, constitutive characters, and the structure of the setting itself" (2008, p. 331).

The different settings in which the securitising actors usually stage their performance are the following: the popular, the elite, the technocratic and the scientific (Salter, 2008). Affecting the way in which the securitiser chooses to present its claims are the different audiences comprised in these settings, as well as the specific rules and procedures that govern them. Employing Salter's classification of settings, it is possible to identify the main moves and their respective audiences in the securitisation of nuclear weapons conducted by the nuclear abolition movement (see Table 1). It is important to remember that, 
in reality, these different settings are all connected, "as they are part of the same policy-making process" (Léonard and Kaunert, 2011, p. 74).

Table 1. Four settings in which the anti-nuclear movement stages its securitising moves

\begin{tabular}{llll}
\hline Setting & Main audience & Main stages & Main securitising moves \\
\hline Elite & Top-rank politicians & $\begin{array}{l}\text { The UNGA and the insti- } \\
\text { tutional bodies of the NPT } \\
\text { review process }\end{array}$ & $\begin{array}{l}\text { Discussions in the Senate/ Parliament; } \\
\text { debates in the UNGA and in the NPT } \\
\text { Review Conferences; international work- } \\
\text { shops; high-level political meetings. }\end{array}$ \\
\hline Popular & General public & $\begin{array}{l}\text { Mainstream media, the } \\
\text { Internet. }\end{array}$ & $\begin{array}{l}\text { Movies; documentaries; music; news- } \\
\text { paper articles; popular demonstrations; } \\
\text { paper handouts. }\end{array}$ \\
\hline Scientific & Academics, scientists & Expert conferences & $\begin{array}{l}\text { Academic publications; expert } \\
\text { conferences. }\end{array}$ \\
\hline Technocratic & Civil servants & $\begin{array}{l}\text { Conference on Disarmament } \\
\text { and the UN Disarmament } \\
\text { Commission. }\end{array}$ & $\begin{array}{l}\text { Debates and negotiations in the Con- } \\
\text { ference on Disarmament and the UN } \\
\text { Disarmament Commission. }\end{array}$ \\
& & &
\end{tabular}

\section{The Technocratic Setting}

If it is true that "the restrictions of mandate and bureaucratic thinking will predominate in technocratic politics" (Salter, 2008, p. 331), then there is no doubt that the CD and the United Nations Disarmament Commissions (UNDC) are, in this case, the main stages of the technocratic setting. These two multilateral fora are characterised by intense debates about their own procedural rules and lack of progress regarding substantial disarmament issues. Moreover, both institutions have quite restrictive policies governing the participation of civil society organisations.

In the $\mathrm{CD}$, for instance, very little of what happens during the many weeks in which the Conference is convened is open to NGOs. Nonetheless, nuclear abolition organisations have found ways to lobby national delegations and engage with the work of the Conference. They can request the official documents of the plenary meetings and follow online reports of NGOs that are present in Geneva and are therefore aware of the discussions inside the CD. NGOs also have the right to submit documents to the $\mathrm{CD}$ and to make written material available to members of the Conference twice a year.

In 2004, the CD agreed to host one informal meeting with NGOs per annual session. However, this can only occur once the CD has adopted a programme of work, which does not happen very often. ${ }^{9}$ Some member-states have emphasised the need to modify

9 After 10 years of impasse, the CD was able to adopt a programme of work in 2009. However, the Conference failed to adopt a framework for implementation before the annual session 
the rules of the CD so that NGOs can be more effectively included in the process, but no substantial improvements have been achieved thus far. ${ }^{10}$

Even though there is little public interest in the UNDC, anti-nuclear NGOs try to follow these meetings. During spring, when the Disarmament Commission meets, the organisations that can make their way to New York hold panel discussions in connection with the UNDC agenda. In order to engage with the member states, NGOs try to organise these events in partnership with national delegations. These informal meetings are one of the stages that nuclear abolitionists created to present their securitising moves in the technocratic setting.

\section{The Scientific Setting}

The scientific setting is mostly made up of nuclear scientists and arms controllers. Considering that these experts possess authoritative knowledge on subjects that are relevant to policy projects, it is tempting to see them as an "epistemic community" (Haas, 1992). This representation, however, may be misleading. As Johnson (2009) has already noted, there are difficulties in presenting these actors as a unified community (p. 198). The political fragmentation of these scientists and arms controllers and the fact that they actually provide competing information and advice makes it more prudent to characterise them in terms of epistemic groups rather than a single community.

Even though this is a somewhat restricted environment, organisations that focus on research and are part of the network of nuclear experts have managed to promote a discourse in favour of nuclear abolition in the stages of the scientific setting. ${ }^{11}$ This is not that difficult, considering that a large number of scientists are openly concerned with the military use of nuclear technology and supportive of the goal of nuclear disarmament. While there is a long tradition of calls for nuclear zero coming from the scientific rank,

ended. When it resumed its work in 2010, the programme of work had to be renegotiated among members, who failed to come to a consensus. Since then, the Conference has not been able to adopt any programme of work and it ended its 2010, 2011 and 2012 sessions without any progress on substantive issues.

10 In the past few years, the Conference has allowed members of the Women's International League for Peace and Freedom (WILPF) to read out a statement on the occasion of International Women's Day. This has been the only chance members of NGOs have had to address the delegates during an official session.

11 The Federation of American Scientists (FAS), the Verification Research, Training and Information Centre (VERTIC), the Stockholm International Peace Research Institute (SIPRI), the International Physicians for the Prevention of Nuclear War (IPPNW) and the International Network of Engineers and Scientists Against Proliferation (INESAP) are all examples of organisations that, to varying degrees, promote securitising moves in the scientific setting. 
one should not overlook the arguments of scientists and arms controllers that advocate for "nuclear security" - which usually involves an increased budget being allocated to further development of nuclear military technology so as to increase the safety, security and reliability of nuclear arsenals.

Evidently, science and politics are very much intertwined in the securitising moves conducted in this setting. For instance, amid the CTBT negotiations in the 1990s, the feasibility of a global system monitoring nuclear tests was a prominent topic of scientific research. Different conferences were organised with the purpose of debating monitoring techniques, which required scientific input from the disciplines of seismology, hydroacoustics, infrasound and radionuclide. Since these scientific exchanges were part of the political battle surrounding the CTBT completion and its subsequent entry into force, they were also part of the different securitising moves in favour of disarmament or deterrence. As the CTBT remains in limbo, the CTBTO - the organisation in charge of the Treaty - continues to promote these scientific meetings, at the same time as it tries to spark the necessary ratifications to bring it into effect. ${ }^{12}$

Although this setting is not completely accessible to the general public, securitisers have explored scientists' expert knowledge in securitising moves aimed at popular or elite audiences. Prior to the invasion of Iraq in 2003, the United Nations Monitoring, Verification and Inspection Commission (UNMOVIC) and the inspections it conducted figured constantly in the political discussions of the US and the UK (Roe, 2008). At present, IAEA inspectors, weapons specialists, scientists and engineers have taken part in the controversy related to the Iranian nuclear programme. Talks about nuclear fuels, the levels of uranium enrichment and the different types of nuclear reactors frequently present a mix of scientific, political and security issues.

\section{The Popular Setting}

Securitising moves in the popular setting declined greatly after the end of Cold War. The turnout in public events aimed at strengthening the calls for nuclear abolition is definitely smaller now than it used to be during the apexes of the movement, in the late 1950s and 1980s. Even so, anti-nuclear activists have continuously used opinion poll results to make the case for abolition, arguing that the general public is in favour of a total elimination of nuclear weapons.

12 In recent years, the CTBTO has hosted the Symposium on Synergies with Science (2006), the International Scientific Studies Conference (2009) and the Science and Technology Conference $(2011,2013)$. The objective of these meetings was to discuss and explore advances in science and technology relevant to test ban verification and the Treaty's entry into force. 
The sources of those opinion polls vary and so does the reliability of such data. Nevertheless, it has been shown that, accurate or not, statistical data can have a real impact on securitisation processes - especially when picked up by the media (Léonard and Kaunert, 2011, p. 69; 70). This, however, has not been the case of the anti-nuclear movement, which remained largely ignored by the mainstream media throughout the 1990s and the 2000s. Counterproliferation, instead of disarmament, has been the perspective favoured by the media to address matters of nuclear security. Accordingly, the controversial nuclear programmes of Iran and North Korea have been extensively covered, but the linkages between nuclear proliferation and the lack of progress towards disarmament have been left unexplored (Tyson, 2004, p. 61).

Other means of communication have contributed to securitisation processes, such as the documentary films An Inconvenient Truth (2006) and Countdown to Zero (2010). From the same producers, the two movies conveyed the sense of urgency associated with the threats of global warming and nuclear weapons, respectively. In what can be seen as a major securitising move in the popular setting, Countdown to Zero featured interviews with leading statesmen and experts, who recounted real life situations in which nuclear weapons had almost been used, as well as times when major nuclear accidents could have happened but were just averted. The Global Zero movement, which promoted the movie to large audiences, described Countdown to Zero as "a chilling wakeup call about the urgency of the nuclear threat" (Global Zero, 2010).

Countdown to Zero opened in movie theatres in different countries, but is currently available online for download. On the internet, one might also find other films, videos, songs and texts that portray the existence of nuclear weapons as an existential threat to human survival. As Vaughn (2009) has observed, securitising moves on the internet can be quite relevant, especially if they are primarily available through news sources or other media outlets (p. 274). Famous musicians, actors, leaders and political figures who support nuclear disarmament also strengthen securitising moves in this setting.

\section{The Elite Setting}

Although securitising actors may require the support of several audiences, the elite setting comprises the central audience of this particular securitisation. Since it is constituted of political leaders who are influential at the global, regional and national levels, this setting effectively congregates audiences "whose attitude has a direct causal connection with the desired goals" (Balzacq, 2005, p. 185); that is, state representatives who have the formal power to start negotiations on a NWC. Even though this setting comprises a variety 
of stages, the most important ones are the United Nations General Assembly (UNGA) and the NPT Review Conferences and Preparatory Committees.

The UNGA has played a significant role in world affairs involving arms control and disarmament norms. Several declarations and resolutions have first been adopted in the United Nations before producing conventions and treaties (Lewis and Thakur, 2004, p. 19). Although not all arms control agreements have been crafted inside UN fora, all the different treaties banning biological and chemical weapons, as well as landmines and cluster munitions, have been developed with the support of a significant number of governments, international organisations and UN agencies. In this particular case, it is expected that a treaty on the prohibition of nuclear weapons will need the support of the UNGA and the UNSC (Andreasen, 2009).

The empowering audience, the one that has the ability to enable the securitising actor to adopt the measures that would tackle the threat, can also be found in the NPT regime and its institutional bodies. As the NPT review process has been gradually opened to NGO participation, the idea of a NWC started to receive more attention from the states' parties. So far, the apex of this trend occurred in the latest NPT Review Conference, in 2010, when numerous states mentioned the NWC in their statements and efforts aimed at commencing negotiations on the NWC were acknowledged in the final document for the first time (NPT Review Conference, 2010).

Still, in the elite setting, it is quite difficult for nuclear abolition organisations to reach the audience. The asymmetry of power between states and non-state actors inside Inter-Governmental Organisations (IGO) and other multilateral fora is significant. Members of civil society organisations can only attend sessions designated as open and, even then, they might not have the right to participate in the discussions. Under special circumstances, NGOs may be allowed to address plenary sessions - but that has not happened frequently in the most important meetings.

Taking all of this into account, it is clear that the elite setting is the most challenging one in this securitisation. In order to understand the obstacles preventing the macrosecuritisation of nuclear weapons from becoming a successful endeavour, it is imperative to analyse in detail the practices of the securitisers in this setting.

\section{Empirical Analysis of the Elite Setting: State Actors and the Campaign for a Nuclear Weapons Convention in the UN General Assembly and the NPT Review Process (1997-2010)}

In the elite setting, the securitisers are the nuclear abolition organisations that have more prominently conducted securitising moves in the UNGA and the institutional bodies 
of the NPT, mainly: the International Physicians for the Prevention of Nuclear War (IPPNW), the International Association of Lawyers Against Nuclear Arms (IALANA), the International Network of Engineers and Scientists Against Proliferation (INESAP) and the International Campaign to Abolish Nuclear Weapons (ICAN). ${ }^{13}$ The time frame analysed encompasses the period from 1997, when the draft NWC was circulated in the UNGA for the first time, to the 2010 NPT Review Conference.

In between these two events, the securitisers delivered presentations at the NPT Review Conferences of 2000 and 2005, as well as the NPT Preparatory Committees of 2002, 2003, 2004, 2007, 2008 and 2009. The datasets available for each of these occasions varied. In addition to the written statements that were always accessible, it was possible to analyse video footage of the NGOs' presentations at the 2005 and 2010 NPT Review Conferences. Audio records of the presentations delivered during the 2007 Preparatory Committee were also examined. The two versions of the NWC that became official UN documents of the fifty-second and sixty-second session, together with the introductory letters signed by representatives of Costa Rica and Malaysia, were included in the empirical analysis. The same is true for the working papers on the NWC submitted to the NPT Review Conferences of 2000, 2005 and 2010, as well as the 2007 NPT Preparatory Committee [See Table 2 for an overview of the dataset analysed. The complete list of reviewed documents can be found in Dalaqua (2011), Appendix 1].

Table 2. Overview of the data analysed

\begin{tabular}{|c|c|}
\hline Occasion & Dataset \\
\hline $\begin{array}{l}\text { Fifty-second session of the UNGA } \\
\text { (1997) }\end{array}$ & Official documents and resolutions \\
\hline 2000 NPT Review Conference & Working paper on the NWC; NGO presentations (written statements) \\
\hline 2002 NPT Preparatory Committee & NGO presentations (written statements) \\
\hline 2003 NPT Preparatory Committee & NGO presentations (written statements) \\
\hline 2004 NPT Preparatory Committee & NGO presentations (written statements) \\
\hline 2005 NPT Review Conference & $\begin{array}{l}\text { Working paper on the NWC; NGO presentations (video footage and written } \\
\text { statements) }\end{array}$ \\
\hline 2007 NPT Preparatory Committee & $\begin{array}{l}\text { Working paper on the NWC; NGO presentations (audio records and written } \\
\text { statements) }\end{array}$ \\
\hline $\begin{array}{l}\text { Sixty-second session of the UNGA } \\
(2007)\end{array}$ & Official documents and resolutions \\
\hline 2008 NPT Preparatory Committee & NGO presentations (written statements) \\
\hline 2009 NPT Preparatory Committee & NGO presentations (written statements) \\
\hline 2010 NPT Review Conference & $\begin{array}{l}\text { Working paper on the NWC; NGO presentations (video footage and written } \\
\text { statements) }\end{array}$ \\
\hline
\end{tabular}

13 As one anonymous reviewer noted, the anti-nuclear organisations represented in these international fora are often based in European and North American countries. 


\section{Methodology}

With the purpose of understanding the process through which this specific public issue - the existence of nuclear weapons - becomes a security concern at the global level, discourse analysis is used to uncover the structures and practices that are involved in the construction of a threat. By employing discourse analysis, other securitisation studies have been able to map the "emergence and evolution of patterns of representation which are constitutive of a threat image" (Balzacq, 2011b, p. 39). Following this practice, it is expected that discourse analysis of the most central texts ${ }^{14}$ produced by the securitising actors will shed light on the sources, mechanisms and effects of the construction of nuclear weapons as a threat to the survival of all humankind.

Traditionally, discourse analysis has been mainly concerned with the content of the discourses, rather than the larger process in which such discourses are immersed. A range of scholars who considered such a focus to be misleading started to promote a different conception of discourse analysis, which became known as Critical Discourse Analysis (CDA) (Fairclough, 1992; Wodak and Meyer, 2001). Considering that discourse is a part of social life and is therefore inherently intersubjective, scholars associated with the CDA perspective have argued that discourse should be studied in its interaction with other discourses. Moreover, they have asserted the need to take into account the larger contextual frame in which discourse is produced, delivered and consumed (Hardy and Phillips, 2004).

From the perspective of the CDA, discourses are considered social practices, as well as representations of social practices. Discourses are resources that are activated by people in the construction of meaning about the world as much as they are practices that structure the meaning in use (Balzacq, 2011b, p. 39). As Fairclough (2003) has demonstrated, any process of "meaning-making" is invariably intersubjective and context dependent. Likewise, constructing a given issue as a security concern presupposes interaction between the securitising actor and the relevant audience(s), which are all situated in a specific time and place.

In order to fully understand the discourse promoted by the securitiser, it is necessary to develop a framework for analysis in which the speakers' interlocutors are properly represented and the immediate and distal contexts are also taken into account. Therefore, for the purpose of guiding the discourse analysis of the selected case studies, a customised

14 Although the term "text" strongly suggests written language, it is used here to refer to a more diverse set of forms. A materialisation of discourse, texts can include a variety of signs (written and spoken utterances, symbols, pictures, music) - all capable of conveying meaning in a certain context (Balzacq, 2011b, p. 39). 
framework for analysis was developed. Following Balzacq's (2011b) suggestion, it comprises three different levels: agents, acts and context (p. 35).

The first level encompasses the actors and relations that structure the securitisation, while the second one comprises the discursive and non-discursive practices that underwrite the securitisation process. The third level provides for the way contextual factors can empower or disempower the securitising actors (Balzacq, 2011b, p. 35; 36).

This methodological construction is intended to facilitate the study of the securitisation process as a whole. If the levels of analysis follow Balzacq's proposal, the same is not true for the constituent analytics within each level. The framework here developed deviates reasonably from his proposed scheme, as items particularly relevant to the study of the anti-nuclear macrosecuritisation have been introduced. The overall result is a comprehensive yet practical framework for analysis (see Table 3).

Table 3. Framework for discourse analysis

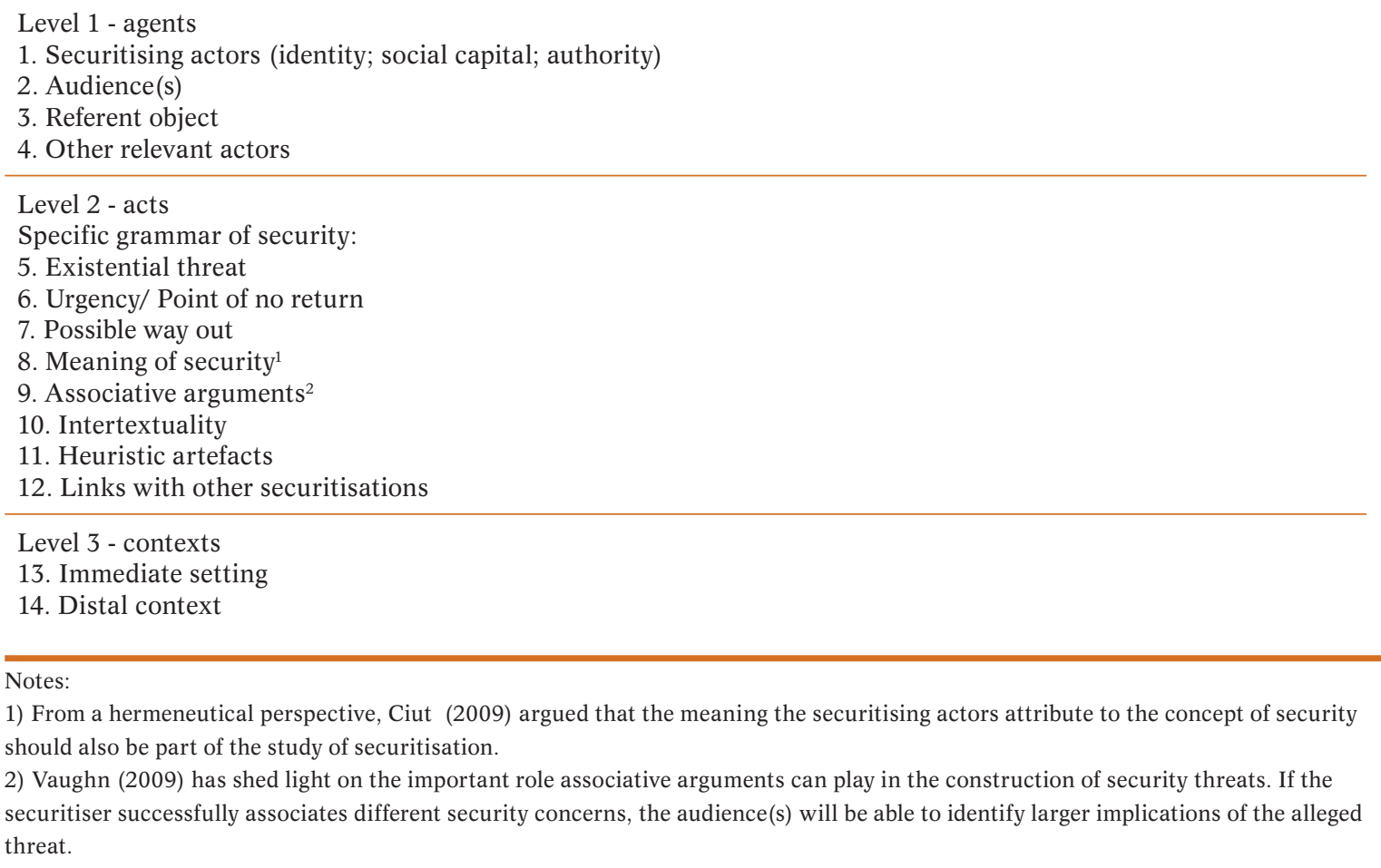

\section{Findings}

The findings of the empirical analysis revealed a consistent discourse, with no substantial variations throughout the years. The securitisers behave professionally, following the protocols of the stages and adjusting their language and the content of their discourse to the audience's frame of reference. They base their social capital upon notions of 
representativeness, introducing themselves as "we the people" and stating "we represent millions of people worldwide" (Hall, 2005). Technical expertise is another source of social capital, as the securitisers often mention their experience with the Landmine Ban and the Cluster Munitions Convention (UN General Assembly 1997a, 2008; Williams, 2010).

Frequently, NGO members portray themselves as representatives of the people, in opposition to the audience, who they see as representatives of states. This differentiation is intended to increase the securitisers' moral authority, as seen in the following statement: "while governments remain the ultimate decision-makers, it is NGOs that allow citizens across the globe to partake in the political process and make their voices heard" (Hall, 2005). Also, by emphasising the power of the audience, who they say can put the relevant security action in place, members of nuclear abolition organisations try to put pressure on representatives of states: "we need more statesmen with a political will to take us to total nuclear disarmament. Ladies and Gentlemen, this is the time and here is your chance" (Ramdas, 2000).

In the elite setting, the securitisers follow the specific grammar of security, arguing that the existence of nuclear weapons poses a threat to the survival of humankind. In making of the threat, the securitiser commonly uses three main sources of arguments: (1) particular features of nuclear weapons, (2) potential incidents involving nuclear weapons and (3) foreseeable consequences of the use of nuclear weapons. They always depict an alarming situation in which the NPT is in crisis and the world is on the verge of a nuclear catastrophe: "Mr Chairman, distinguished delegates, ladies and gentlemen, more bad news" (Cipolat, 2007). The "bad news" exposed by the securitisers primarily refer to the NWS' lack of commitment to disarmament measures. Their failure to disarm is usually presented in connection with the spread of nuclear weapons to other countries (Burroughs, 2005, 2009).

Accordingly, the securitisers argue that the time to act is now, otherwise, another use of nuclear weapons will most likely follow, as "the world does not have the luxury of too much more time" (Williams, 2010). Finally, they present the abolition of nuclear weapons under a NWC as the only alternative to a horrifying future, saying that "going down to three zeros, as in 1000, is not enough" (Weiss, 2009), "abolition is the only way" (Hall, 2005).

The anti-nuclear activists also try to delegitimise nuclear deterrence and dissociate it from the notion of security, affirming that nuclear deterrence provides only an illusion of security (Snyder, 2008) and the possession of nuclear weapons does not make people and states safe. In their view, the "nuclear balance of terror" fosters insecurity rather than security (Spies, 2005). Conversely, they always identify disarmament with security. 
In addition to security utterances, securitisers employ economic factors that can enhance their case against nuclear weapons, like the estimated costs of producing, replacing, maintaining and operating nuclear warheads in each of the NWS (Cabasso, 2007; Loretz, 2007). They also make use of legal arguments, such as the legal obligation to disarm, as stated in Article VI of the NPT and the 1996 ICJ advisory opinion on the legality of the threat or use of nuclear weapons, which asserted that such legal obligation must be fulfilled (UN General Assembly 1997a, 2008; Mitchel, 2009; Weiss, 2000). The securitisers also argue that the use of nuclear weapons should be considered a war crime, as well as a crime against humanity (Johnson, 2010). Additionally, political reasons are present in the securitising claims, since the securitisers frequently mention UNGA resolutions and declarations made by the UN Secretary General in favour of nuclear disarmament.

The constraints imposed by the rules governing this setting have, in fact, encouraged the anti-nuclear organisations to work together. In face of the limited time they have to address the audience, the activists focus on the common positions within the movement and avoid exposing internal disagreements. As one speaker put it: "we enter this room with a clear sense of purpose and a unified voice" (Snyder, 2004). Another consequence of the procedural limitations is the scarce interaction between the securitiser and the audience, as the three-hour session devoted to the NGOs is consumed by presentations and commonly ends with no time left for an exchange of ideas and discussions.

Finally, it was possible to see the impact of the larger contextual configuration on the securitising discourse. After the 2005 NPT Review Conference, in which the NPT states failed to adopt a final document with concrete recommendations for preventing proliferation or moving toward nuclear disarmament, the securitisers raised the alarmist tone of their discourse. Moreover, the nuclear explosions conducted by the Democratic People's Republic of Korea (DPRK), the suspicions around the Iranian programme and reports of an emerging nuclear black market were all contextual factors that served to strengthen the urgency of their calls.

Remarkably, since 2007, the securitisers have been depicting a favourable political configuration regarding the commencement of negotiations on a NWC, arguing that "the security environment is changing, the cold war fogs are clearing" (Johnson, 2010). They continue to emphasise the negative developments surrounding the NPT regime, but they also highlight the growing political support for nuclear disarmament. In the securitising discourse, not only does the world need to move towards nuclear abolition now but the current political configuration is also favourable to it. This fortunate temporal coincidence has served to enhance the urgency of adopting the security measure even more, since the securitisers argue that action must be taken now, before "night falls again" (Johnson, 2010). 


\section{Conclusion}

The new nuclear disarmament momentum, evident since 2007, and the developments regarding the concept of macrosecuritisation demonstrated the relevance and the viability of examining the nuclear abolition movement from an original perspective. Although the causal influence of the nuclear abolition movement on the political decisions regarding acquisition, use or dismantlement of nuclear weapons is beyond the reach of the theory of securitisation, and perhaps beyond the reach of any theory (Vuori, 2010, p. 275), the securitisation framework provided the lens through which to examine the anti-nuclear macrosecuritising discourse.

Combining this theory with discourse analysis, it was possible to see that, in the campaign for a NWC, the anti-nuclear organisations present the logic of zero as driven by a threat. As Buzan et al. (1998) have observed, to phrase things in security terms is always a choice, "not an objective feature of the issue or the relationship itself" (p. 211). In principle, the logic of disarmament could be driven by other factors, such as legal, political, economic or moral arguments. However, states have usually framed nuclear weapons in terms of threat/defence and, while addressing this audience, the securitisers tread a similar path.

Certainly, genuine fear that these weapons may be used again exists, but this does not fully explain the decision to promote a securitising discourse. In the military sector, the logic of threat has usually provided the optimal base for a successful argument. The instrumentality of the securitising discourse becomes apparent; in this case, the alarmist tone of the discourse provides these non-state actors with a loud voice in international military affairs. As Vuori (2008) has noted, "security can be utilized for achieving several political aims" (p. 76). This particular securitisation process is aimed at raising an issue on the agenda of decision-makers and urging them to take action.

Admittedly, the continued existence of (thousands of) nuclear weapons demonstrates that the anti-nuclear discourse has failed to reach its final objective. However, as the issue is again being discussed as part of a wider political debate reassessing the costs and benefits of nuclear deterrence, the endorsement of the description of the threat as existential might become stronger and more widespread.

Even though the solution proposed by the securitisers has so far been rejected and there are no indications that serious negotiations on a NWC will happen any time soon, there is no reason to rule out this possibility. As Krepon (2007) has noted, "nuclear disarmament is a process, not an on-or-off switch". Similarly, every securitisation is a historical process (Balzacq, 2005, p. 193) and this one has been going on for more than half a century and might continue for as long as it takes. 
Many are sceptical of the feasibility of nuclear abolition. It is true that nuclear weapons, like any other human creation, cannot be "disinvented". They can, however, be prohibited and dismantled. As Acton and Perkovich (2009) have observed, civilisation has been capable of doing so in cases where the artefacts in question were considered too dangerous, damaging or morally objectionable to continue living with (p. 17). For instance, the mass-scale gas chambers used by Nazi Germany have not been disinvented, but they are nevertheless not tolerated (Ibid.). Similarly, there is nothing intrinsic to nuclear weapons that makes their elimination impossible. It is up to us - academics, scientists, activists, political leaders, NGOs - to work on the conditions that will lead to the establishment of an international regime capable of verifying the dismantlement of nuclear weapons and minimising the risk of cheating. It is by no means an easy task, but political will and leadership coupled with monitoring technologies can overcome the large majority of the possible obstacles on the way to zero.

Revised by Priscila Moura

Submitted in July 2012

Accepted in May 2013

\section{References}

ADLER, Emanuel. (1992), "The emergence of cooperation: National epistemic communities and the international evolution of the idea of nuclear arms control". International Organization, vol.46, nº1, pp. 101-45.

ANDREASEN, Steve. (2009), "A Joint Enterprise: Diplomacy to Achieve a World without Nuclear Weapons". Arms Control Today [online] vol. 39 (April). Available at: http://www. armscontrol.org/act/2009_04/Andreasen [Retrieved on 27 June, 2011].

BALZACQ, Thierry. (2005), "The three faces of securitization: Political agency, audience and context”. European Journal of International Relations. vol. 11, n 2, p. 171.

BALZACQ, Thierry. (2011a), "A theory of securitization: origins, core assumptions, and variants". In: BALZACQ, Thierry (ed.), Securitization theory: How security problems emerge and dissolve. New York: Routledge.

BALZACQ, Thierry. (2011b), "Enquiries into methods: a new framework for securitization analysis". In: BALZACQ, Thierry (ed.), Securitization theory: How security problems emerge and dissolve. New York: Routledge.

BURROUGHS, John. (2005), "General and Complete Disarmament". Presentation given on 11 May, 2005 at the 2005 NPT Review Conference. NY [video footage and written statement]. Available at: http://www.un.org/en/conf/npt/2005/statements11may.html [Retrieved 11, July 2011].

BURROUGHS, John. (2009), "The Imperative of Good Faith”. Presentation given on 9 May, 2009 at the 2009 Preparatory Committee. NY [written statement]. Available at: http://www. 
lopsr - "Securing our Survival (SOS)": Non-State Actors and the Campaign for a Nuclear Weapons Convention through the Prism of Securitisation Theory

reachingcriticalwill.org/legal/npt/prepcom09/ngostatements/GoodFaith.pdf [Retrieved on 11 July, 2011].

BUZAN, Barry; WAEVER, Ole; WILDE, Jaap de. (1998), Security: A new framework for analysis. Boulder, Colo.: Lynne Rienner Pub.

BUZAN, Barry and WAEVER, Ole. (2003), Regions and Powers: The structure of international security. Cambridge; New York: Cambridge University Press.

BUZAN, Barry and WAEVER, Ole. (2009), "Macrosecuritisation and security constellations: Reconsidering scale in securitisation theory". Review of International Studies, vol. 35, $\mathrm{n}^{\circ} 02, \mathrm{pp} .253-76$.

CABASSO, Jacqueline. (2007), Presentation given on 02 May, 2007 at the 2007 NPT Preparatory Committee. Vienna [audio record and written statement]. Available at: http://www. reachingcriticalwill.org/legal/npt/prepcom07/NGOpres.html [Retrieved on 11 July, 2011].

CIPOLAT, Urs. (2007), "Vertical Proliferation - Russia". Presentation given on 02 May, 2007 at the 2007 NPT Preparatory Committee. Vienna [audio record and written statement]. Available at: http://www.reachingcriticalwill.org/legal/npt/prepcom07/NGOpres.html [Retrieved on 11 July, 2011].

CIUTÃ, Felix. (2009), "Security and the problem of context: A hermeneutical critique of securitisation theory". Review of International Studies. vol. 35, $\mathrm{n}^{\circ}$ 02, pp. 301-26.

CORERA, Gordon. (2008), "Group seeks nuclear weapons ban", BBC News [online], 10 December, 2008. Available at: http://news.bbc.co.uk/2/hi/europe/7774584.stm [Retrieved on 24 April, 2011].

DALAQUA, Renata H. (2011), "Securing our Survival (SOS)": Non-state actors and the Campaign for a Nuclear Weapons Convention through the prism of securitisation theory. MA dissertation. University College London/ University of Tartu. Full text available at: http://cbs.ut.ee/images/files/theses/renata\%20dalaqua.pdf [Retrieved on 11, July 2011].

FAIRCLOUGH, Norman. (2003), Analysing discourse: textual analysis for social research. New York: Routledge.

FAIRCLOUGH, Norman. (1992), Discourse and Social Change. Oxford: Polity.

GLOBAL ZERO COMMISSION. (2009), "Global Zero Action Plan", 29 June, 2009. Available at: http://www.globalzero.org/files/pdf/gzap_3.0.pdf [Retrieved on 24 April, 2011].

GLOBAL ZERO. (2010), "Countdown to Zero: about the film" [online]. Available at: http://www. globalzero.org/en/film/about [Retrieved on 11 July, 2011].

HAAS, Peter M. (1992), "Introduction: epistemic communities and international policy coordination". International Organization, vol. 46, $\mathrm{n}^{\circ} 1$, pp. 1-35.

HALL, Xanthe. (2005), "Abolition is the only way: introduction to the NGO presentations". Presentation given on 11 May, 2005 at the 2005 NPT Review Conference. NY [video footage and written statement]. Available at: http://www.un.org/en/conf/npt/2005/ statements11may.html [Retrieved on 11 July, 2011].

HARDY, Cynthia and PHILLIPS, Norman. (2004), "Discourse and Power". In: GRANT et al., 
(eds.), The Sage handbook of organizational discourse, London: SAGE, pp. 299-316.

HILL, Felicity. (2007), "The Case for a Nuclear Weapons Convention". Presentation given on 2 May, 2007 at the 2007 NPT Preparatory Committee. Vienna [audio record and written statement]. Available at: http://www.reachingcriticalwill.org/legal/npt/prepcom07/ NGOpres.html [Retrieved on 11 July, 2011].

IALANA, INESAP, IPPNW. (1999), Security and Survival: The case for a Nuclear Weapons Convention, Cambridge: IPPNW.

IALANA, INESAP, IPPNW. (2007), Securing our Survival (SOS): the case for a Nuclear Weapons Convention. Cambridge, MA: IPPNW.

JOHNSON, Rebecca. (2009), Unfinished business: the negotiation of the CTBT and the end of nuclear testing. Geneva: UNIDIR.

JOHNSON, Rebecca. (2010), "The path to a nuclear-free world: the case for a Nuclear Weapons Convention". Presentation given on 7 May, 2010 at the 2010 NPT Review Conference. NY [video footage and written statement]. Available at: http://www.un.org/en/conf/npt/2010/ ngopresentations.shtml [Retrieved on 11 July, 2011].

KI-MOON, Ban. (2008), "The United Nations and security in a nuclear-weapon-free world". New York, 24 October, 2008. Available at: http://www.un.org/apps/sg/printsgstats.asp?nid=3493 [Retrieved on 7 July, 2011].

KREPON, Michael. (2007), "Nuclear Abolition: Then and Now". The Stimson Center [online], 16 July, 2007. Available at: http://www.stimson.org/spotlight/nuclear-abolition-then-andnow/ [Retrieved on 7 July, 2011].

LÉONARD, Sarah and KAUNERT, Christian. (2011), Reconceptualizing the audience in securitization theory. In: BALZACQ, Thierry (ed.), Securitization theory: How security problems emerge and dissolve. New York: Routledge.

LEWIS, Patricia and THAKUR, Ramesh. (2004), "Arms control, disarmament and the United Nations". Disarmament Forum, no 1, pp. 17-28.

LORETZ, John. (2007), "Introduction". Presentation given on 2 May, 2007 at the 2007 NPT Preparatory Committee, Vienna [audio record and written statement]. Available at: http:// www.reachingcriticalwill.org/legal/npt/prepcom07/NGOpres.html [Retrieved on 11 July, 2011].

MITCHELL, Ruth. (2009), "Negotiating a Nuclear Weapons Convention - Framework for a Nuclear-Weapons-Free World". Presentation given on 9 May, 2009 at the 2009 Preparatory Committee, NY [written statement]. Available at: http://www.reachingcriticalwill.org/legal/ npt/prepcom09/ngostatements/NWC.pdf [Retrieved on 11 July, 2011].

NPT Review Conference (2010), Final Document (vol. I) (NPT/CONF.2010/50), 18 June, 2010. Available at: http://www.un.org/ga/search/view_doc.asp?symbol=NPT/CONF.2010/50 (VOL.I) [Retrieved on 7 July, 2011].

PERKOVICH, George, and ACTON, James. (eds.) (2009), Abolishing nuclear weapons: a debate. Available at: www.CarnegieEndowment.org/pubs [Retrieved on 7 July, 2011]. 
RAMDAS, Laxminarayan. (2000), "Concluding Remarks". Presentation given on 3 May, 2000 at the 2000 NPT Review Conference, NY [written statement]. Available at: http://www. reachingcriticalwill.org/legal/npt/NGOpres00/55.pdf [Retrieved on 11 July, 2011].

RISSE-KAPPEN, Thomas. (1994), "Ideas do not float freely: Transnational coalitions, domestic structures, and the end of the Cold War". International Organization. vol. 48, nº2, pp.185214.

ROE, Paul. (2008), "Actor, Audience(s) and Emergency Measures: Securitization and the UK's Decision to Invade Iraq", Security Dialogue, vol. 39, n 6, pp. 615.

SALTER, Mark B. (2008), "Securitization and desecuritization: A dramaturgical analysis of the Canadian air transport security authority". Journal of International Relations and Development. vol. 11, nº 4 , pp.321-49.

SCHULTZ, George; PERRY, William; KISSINGER, Henry; NUNN, Sam. (2008), "Toward a Nuclear Free World", Wall Street Journal, 15 January, 2008.

SCHULTZ, George; PERRY, William; KISSINGER, Henry; NUNN, Sam. (2007), "A World Free of Nuclear Weapons", Wall Street Journal, 4 January, 2007, p. A15.

SNYDER, Susi. (2008), "Recommendations". Presentation given on 29 April, 2008 at the 2008 NPT Preparatory Committee. Geneva [written statement]. Available at: http://www. reachingcriticalwill.org/legal/npt/prepcom08/ngostatements/Recommendations.pdf [Retrieved on 11 July, 2011].

SNYDER, Susi. (2004), "Overview of NGO Presentations". Presentation given on 27 April, 2004 at the 2004 NPT Preparatory Committee. NY [written statement]. Available at: http://www. reachingcriticalwill.org/legal/npt/prepcom04/NGOpres.html [Retrieved on 11 July, 2011].

SPIES, Michael. (2005), "Compliance to Article VI: Nuclear Disarmament". Presentation given on 11 May, 2005 at the 2005 NPT Review Conference. NY [video footage and written statement]. Available at: http://www.un.org/en/conf/npt/2005/statements11may.html [Retrieved 11 July, 2011].

STRITZEL, Holger. (2007), "Towards a theory of securitization: Copenhagen and beyond", European Journal of International Relations. vol. 13, $\mathrm{n}^{\mathrm{0}}$ 3, pp. 357.

THE TREATY on the NON-PROLIFERATION of NUCLEAR WEAPONS (NPT). (1968), Available at: http://www.un.org/en/conf/npt/2010/npttext.shtml [Retrieved on 24 April, 2011].

THE WHITE HOUSE. (2009), Remarks by President Barack Obama. Prague, 5 April 2009. Available at: http://www.whitehouse.gov/the_press_office/Remarks-By-President-BarackObama-In-Prague-As-Delivered/ [Retrieved on 24 April, 2011].

TYSON, Rhianna. (2004), "Contextualizing past, present and future challenges to the NPT regime". Disarmament Forum, no 4, pp. 57-67.

UN ECONOMIC and SOCIAL COUNCIL. (1996), Resolution adopted by the Economic and Social Council 1996/31. Consultative relationship between the United Nations and nongovernmental organizations, 25 July, 1996. Available at: http://www.un.org/documents/ ecosoc/res/1996/eres1996-31.htm [Retrieved on 24 April, 2011]. 
UN GENERAL ASSEMBLY. (1996), Resolution adopted by the General Assembly 51/45. Advisory opinion of the International Court of Justice on the legality of the threat or use of nuclear weapons (A/RES/51/45 M) 10 December, 1996. Available at: http://www.un.org/ documents/resga.htm [Retrieved on 7 July, 2011].

UN GENERAL ASSEMBLY. (1997a), Letter dated 31 October 1997 from the Chargé d'affaires a.i. of the Permanent Mission of Costa Rica to the United Nations addressed to the SecretaryGeneral (A/C. 1 /52 /7), 17 November, 1997.

UN GENERAL ASSEMBLY. (1997b), Resolution adopted by the General Assembly 52/38. ICJ advisory opinion on the legality of the threat or use of nuclear weapons (A/RES/52/38 O) 9 December, 1997. Available at: http://www.un.org/documents/resga.htm [Retrieved on 7 July, 2011].

UN GENERAL ASSEMBLY. (2007), Resolution adopted by the General Assembly 62/39. Followup to the advisory opinion of the International Court of Justice on the Legality of the Threat or Use of Nuclear Weapons (A/RES/62/39) 5 December, 2007. Available at: http:// www.un.org/documents/resga.htm [Retrieved on 7 July, 2011].

UN GENERAL ASSEMBLY. (2008), Letter dated 17 December, 1997 from the Permanent Representatives of Costa Rica and Malaysia to the United Nations addressed to the Secretary-General (A/62/650), 18 January, 2008.

VAUGHN, Jocelyn. (2009), "The unlikely securitizer: Humanitarian organizations and the securitization of indistinctiveness". Security Dialogue, vol.40, n³, pp. 263-85.

VUORI, Juha (2008), "Illocutionary logic and strands of securitization: Applying the theory of securitization to the study of non-democratic political orders". European Journal of International Relations, vol.14, $\mathrm{n}^{\circ} 1$, pp. 65.

VUORI, Juha A. (2010), "A timely prophet? The doomsday clock as an aesthetisation of securitization moves with a global referent object". Security Dialogue, vol.41, n³, pp. 255-274.

WEISS, Peter. (2009), "Introduction". Presentation given on 9 May, 2009 at the 2009 Preparatory Committee, NY [written statement]. Available at: http://www.reachingcriticalwill.org/legal/ npt/prepcom09/ngostatements/Introduction.pdf [Retrieved on 11 July, 2011].

WEISS, Peter. (2000), "The NPT and the law". Presentation given on 3 May, 2000 at the 2000 NPT Review Conference. NY [written statement]. Available at: http://www.reachingcriticalwill. org/legal/npt/NGOpres00/29.pdf [Retrieved on 11 July, 2011].

WILLIAMS, Jody. (2010), Presentation given on 7 May, 2010 at the 2010 NPT Review Conference. NY [video footage]. Available at: http://www.un.org/en/conf/npt/2010/ngopresentations. shtml [Retrieved on 11 July, 2011].

WITTNER, Lawrence S. (1993), The struggle against the Bomb. Stanford nuclear age series. vol. 1. One world or none. Stanford, California: Stanford University Press.

WITTNER, Lawrence S. (1997), The struggle against the Bomb. Stanford nuclear age series. vol. 2. Resisting the Bomb. Stanford, California: Stanford University Press.

WITTNER, Lawrence S. (2003), The struggle against the Bomb. Stanford nuclear age series. vol. 3. Toward nuclear abolition. Stanford, California: Stanford University Press. 
bpsr - "Securing our Survival (SOS)": Non-State Actors and the Campaign for a Nuclear Weapons Convention through the Prism of Securitisation Theory

WODAK, Ruth and MEYER, Michael (eds.). (2001), Methods of critical discourse analysis. London: Sage Publications.

WRIGHT, Tim. (2010), Non-Proliferation Treaty Review Conference: Towards Nuclear Abolition [online]. Available at: http://www.icanw.org/files/RevCon2010_1.pdf [Retrieved on 21 July, 2011]. 